\section{Analisis Daya Dulkung Pondasi Menggunakan Hasil Uji CPT Dan Uji Laboratorium Pada Bangunan Guest House}

\author{
Priyo Suroso ${ }^{1}$ Darmansyah Tjitradi ${ }^{2,3}$ \\ 1 Program Studi Teknik Sipil Politeknik Negeri Samarinda \\ 2 Program Studi Pendidikan Profesi Insinyur, Universitas \\ Lambung Mangkurat \\ ${ }^{3}$ Persatuan Insinyur Indonesia Wilayah Kalimantan Selatan
}

priyosuroso@polnes.ac.id

\section{Pendahuluan}

Proyek pembangunan konstruksi dalam dasa warsa terakhir cukup signifikan dihampir seluruh pelosok negeri tercinta Indonesia. Tidak terkecuali Kalimantan Timur yang masih sangat menjanjikan bagi para pekerja jasa konstruksi. Kondisi ini didorong oleh kebutuhan akan tempat tinggal sebagai tempat kegiatan manusia sehari-hari, pusat bisnis dan hiburan serta pusat pemerintahan. Bangunan hunian yang digunakan oleh masyarakat maupun pemerintahan harus tetap stabil berdiri diatas tanah. Namun sering terjadi pembangunan tidak memperhatikan keamanan konstruksi tetapi hanya mengejar keuntungan, sehingga pentingnya pondasi suatu bangunan sering tidak diperhatikan. Kestabilan bangunan berdiri sangat ditentukan oleh topangan tanah disekelilingnya terhadap pondasinya. Seperti dinyatakan Suryolelono (2004) bahwa struktur bangunan terdiri dari struktur bawah dan struktur atas. Struktur bawah adalah pondasi bangunan yang harus mampu meneruskan struktur atas ke tanah pendukungnya sehingga memberikan keamanan struktur atas. Bentuk dan jenis pondasi sangat tergantung dari daya dukung dan besarnya penurunan tanah yang terjadi. Bagian terbawah dari bangunan adalah Pondasi yang berfungsi untuk meneruskan beban ke tanah. Dan membedakan pondasi dari kedalaman pondasi (Df) dan
Perkembangan suatu daerah akan diikuti pula perkembangan dibidang jasa konstruksi. Tingkat kenyamanan dan ketenangan bagi pemakai suatu bangunan maka faktor keamanan menjadi suatu hal yang penting. Kestabilan suatu bangunan gedung, daya dukung tanah sebagai pijakannya harus diketahui terlebih dahulu sebelum dibangun. Uji-uji untuk mengetahui sifat-sifat tanah, berguna mengetahui daya dukung tanah yang dapat dilakukan di lapangan maupun di laboratorium. Salah satu uji di lapangan yang praktis dan mudah dilakukan adalah uji CPT (sondir), Analisis dari uji ini dapat diterapkan dalam menentukan dimensi dan jenis pondasi yang dipergunakan. Rencana pembangunan Guest House analisis pondasinya berdasarkan hasil uji CPT kombinasi dengan uji laboratorium dan metode analisisnya menggunakan metode Skempton (1951) untuk pondasi dangkal dan metode Bagemann (1965) pondasi tiang. Hasil analisisnya diperoleh pondasi dangkal yang bangunannya beban ringan dapat digunakan dimensi pondasi bujur sangkar ukuran o,75 m dan $1 \mathrm{~m}$ sampai kedalaman $2 \mathrm{~m}$. Hasil yang diperoleh untuk pondasi tiang dapat digunakan tiga model bentuk segitiga, bujur sangkar dan lingkaran.

Kata kunci: CPT, pondasi, penurunan, daya dukung,

Diajukan: 7 Mei 2020

Direvisi: 24 Juni 2020

Diterima: 24 Oktober 2020

Dipublikasikan online: 26 Oktober 2020

lebar (B). Pondasi dalam bila Df/B > 4 dan pondasi dangkal bila Df/B $\leq 1$ (Hardiyatmo, 2011).

Kapasitas daya dukung tanah sangat ditentukan sifat fisik maupun mekanisnya. Dalam teknik sipil, tanah adalah material endapan yang butirannya bersifat lepas-lepas (loose) dan jenisnya tanah kohesive dan non kohesive. Sifat fisik dan karakteristik kedua jenis tanah sangat jauh berbeda satu sama lain. System klasifikasi terpadu tanah atau dikenal Unified Soil Classification System (USC), ditentukan berdasarkan pengujian ukuran butiran dan plastisitas tanah (Terzaghi dan Peck, 1967). Sifat-sifat tanah dapat ditentukan pula dari pengujian di lapangan yaitu Standar Penetration Test (SPT), Cone Penetration Test (atau CPT), uji plat beban, dan uji baling-baling geser (Vane Share Test). Alat uji CPT (sondir) merupakan alat yang praktis, mudah dioperasikan dan langsung diperoleh hasilnya. Dimana hasilnya dapat dipergunakan untuk menganalisis daya dukung tanah suatu pondasi. Bahri dkk. (2016) menyatakan bahwa berdasarkan hasil uji CPT, analisis daya dukung tanah uji sondir di Pesisir Pantai Bengkulu menunjukkan hasil yang sama dengan nilai konversi uji SPT. Pendekatan penentuan klasifikasi tanah dari uji sondir dikemukakan oleh Robertson dan Campanella (1983) berdasarkan hubungan antara tahanan konus (qc) dengan rasio gesekan fr (Gambar 1).

Cara mensitasi artikel ini:

Priyo S., Darmansyah T. (2020) Analisis Daya Dukung Pondasi Menggunakan Hasil Uji CPT Dan Uji Laboratorium Pada Bangunan Guest House. Buletin Profesi Insinyur 3(2) 118-121 


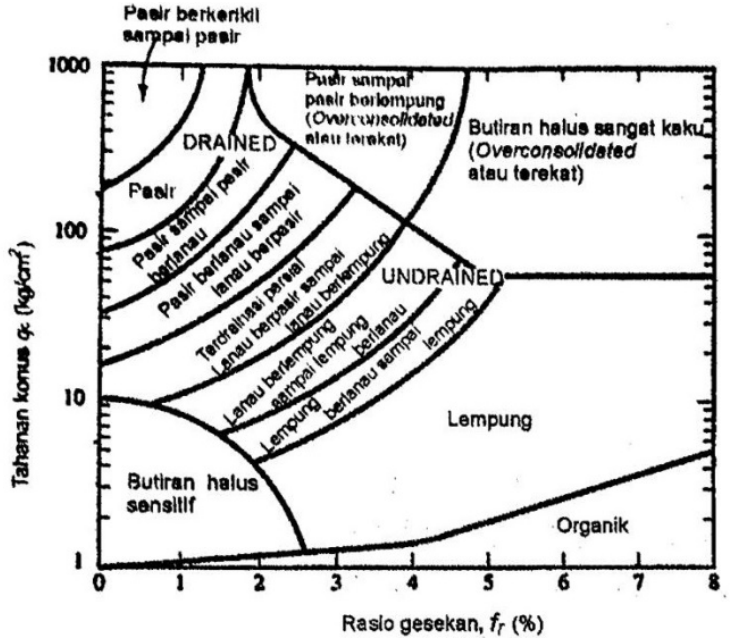

Gambar 1 Klasifikasi tanah berdasarkan hasil uji CPT (Robertson dan Campanella, 1983)

Penurunan pondasi sangat berpengaruh terhadap konstruksi di atasnya, terutama untuk tanah-tanah kelempungan mempunyai penurunan yang tinggi dalam jangka waktu yang lama. Penurunan pondasi pada tanah berbutir halus dan jenuh air terbagi menjadi 3 komponen, yaitu: penurunan segera $\left(\mathrm{S}_{\mathrm{i}}\right)$, penurunan konsolidasi $\left(\mathrm{S}_{\mathrm{c}}\right)$ dan penurunan konsolidasi sekunder (Terzaghi, 1943 dalam Hardiyatmo, 2011). Penurunan tanah terjadi karena adanya beban kerja diatasnya. Prediksi besar penurunan memerlukan keakuratan data hasill uji di laboratorium mendekati kondisi tanah di lapangan (Nawir dkk., 2012).

Perencanaan pondasi dangkal maupun pondasi dalam selalu memperhatikan keamanan struktur di atasnya dan faktor ekonominya. Oleh karena itu pada analisis daya dukung pada Pembangunan Guest House ini selain analisis daya dukung juga dilakukan analisis terhadap prediksi besar penurunan pondasi terutama pada pondasi dangkal.

\section{Metode}

Analisis daya dukung tanah pertama-tama dilakukan pengujian tanah di lapangan menggunakan alat sondir sejumlah 4 titk uji yang tersebar pada area rencana Pembangunan seperti pada Gambar 2. Pelaksanaan uji sesuai SNI 2827:2008 dan digunakan kapasitas tahanan konus $>250 \mathrm{~kg} / \mathrm{cm}^{2}$ IGambar 3). Pengambilan contoh tanah tidak terganggu (undisturb sample) sesuai SNI 03-6802-2002.

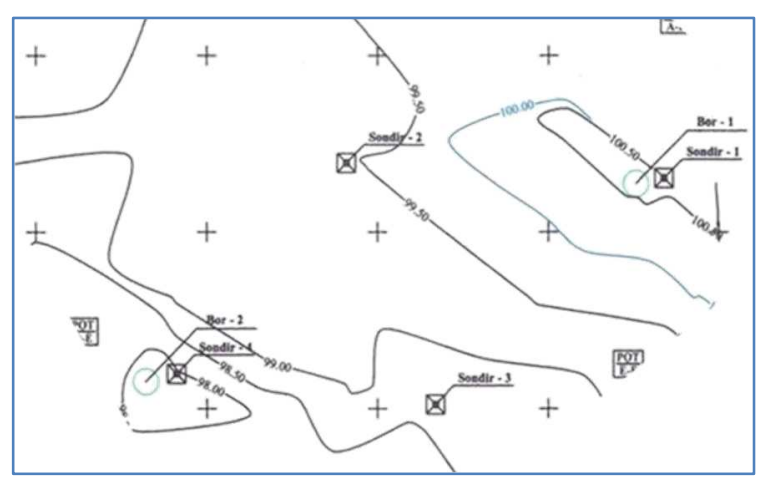

Gambar 2 Area titik uji sondir

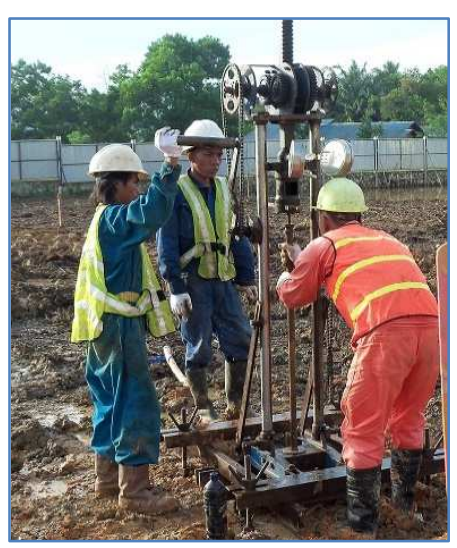

Gambar 3 Pengujian CPT (sondir)

Pengujian laboratorium digunakan standar seperti dalam Tabel 1 berikut.

Tabel 1 Daftar standar uji laboratorium

\begin{tabular}{cll}
\hline Nomor & \multicolumn{1}{c}{ Pengujian } & \multicolumn{1}{c}{ Standar } \\
\hline 1 & kadar air & SNI 03-1964-1990 \\
2 & berat jenis & SNI 03-1965-1990 \\
3 & berat volume & SNI 03-3637-1994 \\
4 & distribusi butiran & SNI 03-3423-1994 \\
5 & Batas cair & SNI 03-1967-1990 \\
6 & Kuat tekan bebas & SNI 03-3638-1994 \\
7 & Geser langsung & SNI 03-3420-1994 \\
8 & Konsolidasi & SNI 03-2812-1992
\end{tabular}

Metode analisis daya dukung ultimit pondasi dangkal pada tanah lempung digunakan metode Skempton (1951) dan penurunan pondasi metode Terzaghi (1943). Analisis pondasi dalam digunakan metode Bagemenn (1965).

\section{Hasil Kerja}

\section{Hasil pengujian tanah}

Klasifikasi dan lapisan tanah merujuk usulan Robertson dan Campanella (1983) secara umum berupa lempung lunak berorganik dari permukaan sampai kedalaman berkisar 1 meter dengan nilai konus berkisar $3 \mathrm{~kg} / \mathrm{cm}^{2}$. Kemudian sampai kedalaman sekitar $4 \mathrm{~m}$ berupa tanah lempung lunak dengan nilai konus berkisar $5 \mathrm{~kg} / \mathrm{cm}^{2}$. Pada kedalaman berkisar $6 \mathrm{~m}$ berupa lensa tanah pasir berlanau setebal $60 \mathrm{~cm}$ dengan nilai konus berkisar 8 $\mathrm{kg} / \mathrm{cm}^{2}$. Pada kedalaman berkisar $8 \mathrm{~m}$ berupa tanah pasir berlanau dengan nilai konus berkisar 11 $\mathrm{kg} / \mathrm{cm}^{2}$. Pada kedalaman $10 \mathrm{~m}$ berupa tanah lanau pasir dengan nilai konus berkisar $20 \mathrm{~kg} / \mathrm{cm}^{2}$. Kedalaman tanah keras dengan nilai tahanan konus $>150 \mathrm{~kg} / \mathrm{cm}^{2}$ terletak pada kedalaman sekitar $12 \mathrm{~m}$.

Hasil uji laboratorium merujuk Terzaghi and Peck (1967) sampai kedalaman $1 \mathrm{~m}$ jenis tanahnya adalah 
Lanau organic dan lempung berlanau oragnik dengan plastisitas rendah $(O L)$. Sedang kedalaman sampai dengan kurang lebih $12 \mathrm{~m}$ didominasi oleh tanah Lempung tidak organik dengan plastisitas rendah sampai sedang, lempung berpasir, lempung berlanau, lempung kurus $(C L)$.

\section{Analisis daya dukung tanah}

Pembangunan Guest House berupa bangunan satu dan dua lantai, bangunan tersebut akan terletak pada lempung lunak. Jenis fondasi yang sesuai adalah fondasi dangkal untuk fondasi bangunan yang mendukung beban ringan, dan fondasi tiang mini untuk fondasi bangunan yang mendukung beban relatif lebih berat.

Kondisi di lapangan berupa tanah empung, analisis kapasitas dukung ultimit digunakan persamaan Skempton (1951) dalam Hardiyatmo (2010), dan kondisi lempung terkonsolidasi normal (normally consolidated) maka dengan nilai konus $\left(\mathrm{q}_{\mathrm{c}}\right)<20$ $\mathrm{kg} / \mathrm{cm}^{2}$, digunakan $c_{u}=\mathrm{qc} / 18 \mathrm{~s} / \mathrm{d} \mathrm{qc} / 15$. Faktor kapasitas dukung $N_{c}$ diambil dari Gambar 4 .

Daya dukung ultimit $\left(q_{u}\right)$ besarnya digunakan Persamaan (1), dan daya dukung ultimit neto ( $q_{u n}$ ) menggunakan Persamaan (2), yaitu:

$q_{u}=c_{u} N_{c}+D_{f} \gamma$

$q_{u n}=c_{u} N_{c}$

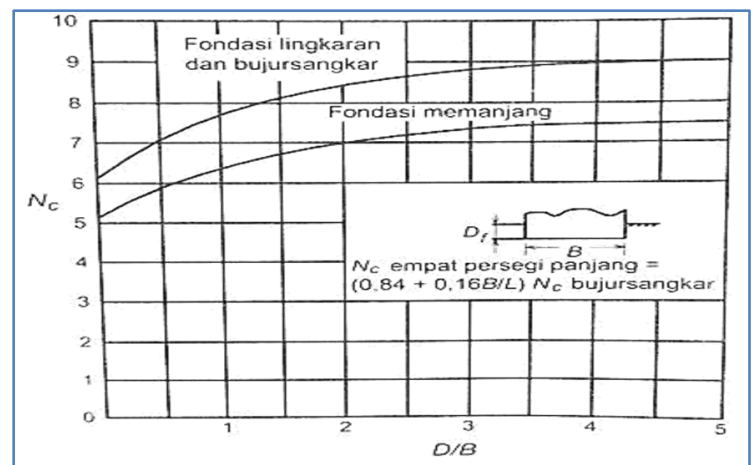

Gambar 4 Faktor kapasitas dukung $N_{c}$ (Skempton, 1951)

Pondasi yang dipergunakan berbentuk empat persegi panjang dan dengan memperhatikan kondisi tanah di lapangan berupa lempung lunak, maka diambil nilai modulus Elastis $\mathrm{E}=4000 \mathrm{kN} / \mathrm{m}^{2}$ (Bowles, 1996) dan pondasi dianggap fleksibel maka $I_{p}=1,00$ (Terzaghi, 1943 dalam Hardiyatmo, 2011). Tekanan pondasi pada tanah sebesar nila $\mathrm{q}_{\mathrm{n}}=\mathrm{q}_{\mathrm{c}}=30 \mathrm{kPa}$, penurunan segera $\left(\mathrm{S}_{\mathrm{i}}\right)$ dianalisis dengan Persamaan (3).

$S_{i}=\left(q_{n} B / E\right)\left(1-\mu^{2}\right) I_{p}$

Penurunan konsolidasi primer diselesaikan dengan menggunakan Persamaan (4) untuk tanah lempung normally consolidated $\left(\mathrm{p}_{\mathrm{c}}{ }^{\prime}=\mathrm{p}_{\mathrm{o}}{ }^{\prime}\right)$ dengan tegangan efektif sebesar $\mathrm{p}_{1}{ }^{\prime}$, besarnya adalah:

$S_{c}=C_{c}\left(H /\left(1+e_{0}\right)\right) \log \left(P_{1}^{\prime} / p_{0}^{\prime}\right)$
Kedalaman tanah lempung keras berkisar $12 \mathrm{~m}$, maka pondasi bangunan yang menerima beban relative berat digunakan pondasi dalam berupa tiang pancang mini pile. Persamaan (5) adalah untuk menyelesaikan daya dukung ultimit tiang dalam tanah kohesif (Bagemann, 1965) :

$Q_{u}=A_{b} q_{c}+A_{s} f_{s}$

\section{Hasil Analisis pondasi dangkal}

Gambar 5 hasil analisis daya dukung tanah pondasi dangkal. Lebar pondasi (B) bervariasi: $075 \mathrm{~m}, 1 \mathrm{~m}, 1,5 \mathrm{~m}$ dan $2 \mathrm{~m}$, terlihat makin lebar menunjukkan penurunanan daya dukung ijin $\left(q_{a}\right)$. Penurunan daya dukung dipengaruhi oleh menurunnya nilai banding kedalaman dan lebar pondasi $\left(D_{f} / B\right)$, sehingga nilai kapasitas dukung $\left(N_{c}\right)$ menurun. Daya dukung ijin pondasi pada tanah lunak menurut Peraturan Pembebanan Indonesia (PBI) 1983 adalah antara 0,5-2 $\mathrm{kg} / \mathrm{cm}^{2}$. Terlihat pada Gambar 5 pondasi lebar $0,75 \mathrm{~m}$ dan $1 \mathrm{~m}$ daya dukung ijin $<0,5 \mathrm{~kg} / \mathrm{cm}^{2}$.

Gambar 6 adalah hasil analisis penurunan konsolidasi. Penurunan konsolidasi pada pondasi dipengaruhi oleh jenis tanah, makin dalam berat tanah makin besar sehingga tekanan overburden $\left(p_{0}{ }^{\prime}\right)$ menjadi besar berimplikasi pada penambahan beban. Menurut USSR (1995) dalam Suryolelono (2004) penurunan bangunan gedung sederhana yang diijinkan tidak boleh melebihi $10 \mathrm{~cm}$. Terlihat pada Gambar 6 penurunan $<10 \mathrm{~cm}$ terjadi pada pondasi lebar $0,75 \mathrm{~m}$ dan $1 \mathrm{~m}$.

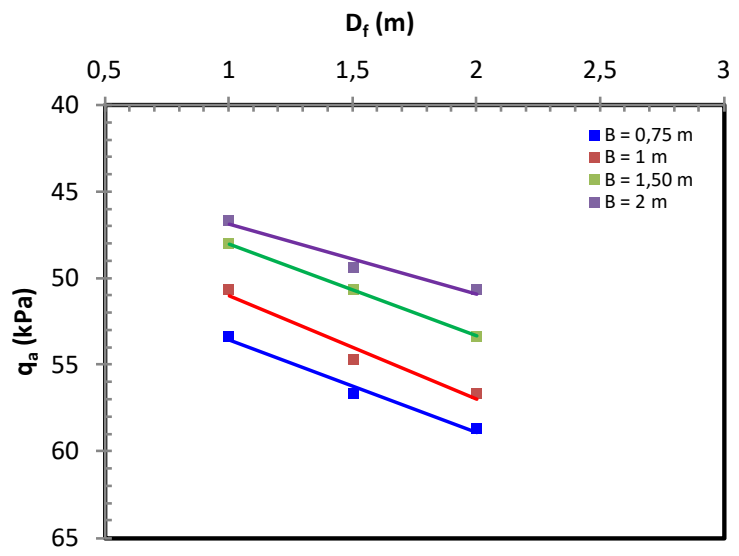

Gambar 5 Grafik hubungan $q_{a}$ vs $D_{f}$ berdasarka lebar pondasi (B)

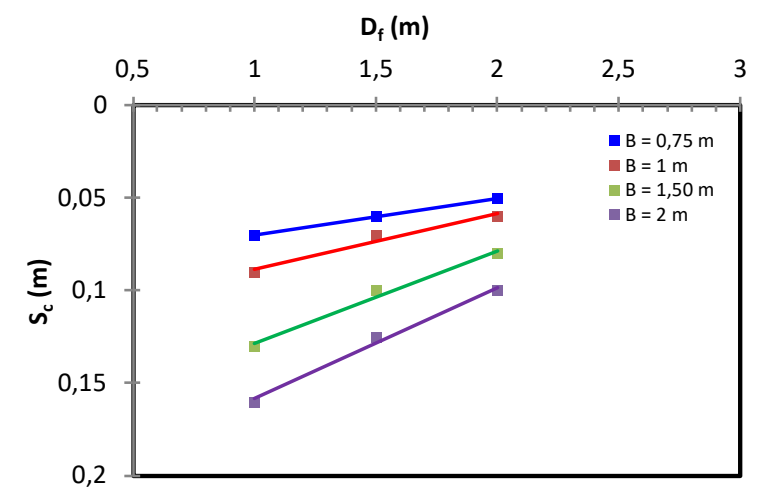

Gambar 6 Grafik hubungan $S_{c}$ vs $D_{f}$ berdasarkan lebar pondasi (B) 


\section{Hasil Analisis pondasi dalam}

Pondasi dalam (tiang) adalah konstruksi bawah dari bangunan apabila lapisan tanah yang mampu mendukung beban di atasnya berada sangat dalam. Terlihat dari hasil sondir kondisi tanah di lapangan tanah bagian atas merupakan tanah lempung lunak dengan nilai qc yang relatif kecil. Oleh karena itu untuk mendukung bangunan Guest house lebih cocok digunakan fondasi fondasi tiang bila beban kolom relatif besar. Gambar 7 menunjukkan hasil analisa daya dukung pondasi tiang dalam 3 bentuk model tiang pancang mini, yaitu; bentuk bulat (lingkaran), segitiga dan bujur sangkar dengan masing-masing berdiameter atau lebar sisi-sisi nya $20 \mathrm{~cm}$. Terlihat dalam Gambar 7 bahwa tiang pancang berbentuk bujur sangkar memberikan nilai daya dukung yang paling tinggi. Hal ini karena mempunyai luas penampang dan selimut tiang yang terbesar, hal ini berpengaruh pada meningkatnya tahanan ujung dan gesek selimut tiang makin besar. Seperti dinyatakan Tomlinson (1994) bahwa pada tiang pancang terjadi mobilisasi tahanan ujung dan gesek tiang bila ada yang membebani tiang. Penentuan factor ekonomi penggunaan tiang pancang perlu diperhatikan, tetapi factor keamanan dari konstruksi juga sangat menentukan kestabilan dari suatu bangunan .

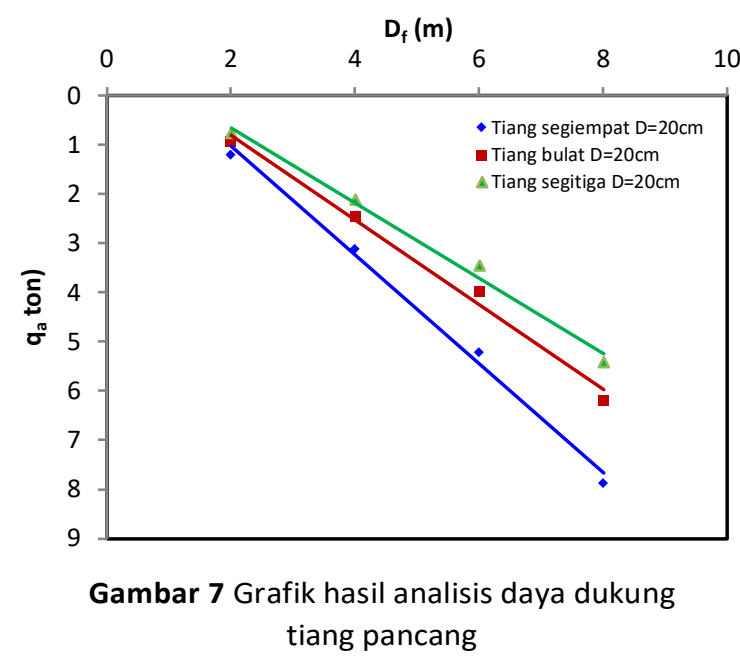

\section{Kesimpulan}

- Pondasi dangkal dapat dipergunakan untuk bangunan dengan beban ringan dan lebar pondasi $0,75 \mathrm{~m}$ dan $1 \mathrm{~m}$ sampai kedalaman $2 \mathrm{~m}$, tetapi perlu dilakukan analisa lanjutan lamanya penurunan.
- Pondasi tiang pancang dapat digunakan dengan ketiga model bentuk tiang, yang perlu diperhatikan adalah ketersediaan dari taing pancang dipasaran.

\section{Ucapan Terimakasih}

Ucapan terimakasih ditujukan kepada Kepala Laboratorium Jurusan Teknik Sipil, Politeknik Negeri Samarinda, yang telah banyak membantu dengan memberikan data-data yang diperlukan.

\section{Referensi}

Bagemann, H.KS. 1965. The Maximum Pulling Force on A Single Tension Pile Calculated on The Basis of Result of The Adhesion Jacked Cone. Proc. $6^{\text {th }}$. Conf. SMFE. Vol.2. pp. 220-233.

Bahri, S., M. K. Razali, K. A. Elsandy (2016). Pemetaan Daya Dukung Tanah Untuk Pondasi Dangkal Di Wilayah Pesisir Pantai Kota Bengkulu. Jurnal Inersia Volume 8 No.1.

Bowles, J.E. 1996. Foundation Analysis and Design. $5^{\text {th }}$ Edition. Singapore. McGraw-Hill Companies, Inc.

Hardiyatmo, H.C. 2010. Analisis dan Perancangan Pondasi Bagian II. Yogyakarta: Gadjah Mada university Press.

Hardiyatmo, H.C. 2011. Analisis dan Perancangan Pondasi I. Yogyakarta: Gadjah Mada university Press.

Nawir, H., D. Apoji, R. Fatimatuzahro, M. Pamudji (2012). Prediksi Penurunan Tanah Menggunakan Prosedur Observasi Asaoka Studi Kasus: Timbunan di Bontang, Kalimantan Timur. Jurnal Tekniik Sipil. Volume 19 No.2.

Peraturan Pembebanan Indonesia Untuk Gedung 1983. 1983. Bandung : Yayasan Lembaga Penyelidikan Masalah Bangunan.

Robertson, P.K. and Campanella, R.G. (1983). Interpretation of Cone Penetration Tests. Canadian Geotechnical Journal. Volume 20. Pp. 718-745.

Skempton, A.W. 1951. The Bearing Capacity of Clays. England : Proc. Build. Res. Congres. London.

Suryolelono, K.B. 2004. Perancangan Pondasi. Yogyakarta: Nafiri.

Terzaghi, K. 1943. Theoritical Soil Mechanics. New York : John Wiley and Sons.

Terzaghi, K., Peck, R.B., G. Mesri (1996) Soil Mechanics in Engineering Practice. Third Edition. New York : John Wiley and Sons.

Tomlinson, M.J. 1994. Pile Design and Construction Practice. Fourth Edition. 2-6 Boundary Row, London SE1 8HN, UK : Published by E \& FN Spon. 